\title{
Antioxidant and antimicrobial capacity of aqueous extract of kale and potential supplementation in fermented dairy beverage
}

\begin{abstract}
Capacidade antioxidante e antimicrobiana do extrato aquoso de couve e potencial
\end{abstract} suplementação em bebida láctea fermentada

\author{
L. C. R. da Silva; A. M. Azevedo; A. C. Almeida; F. S. A. da Fonseca; I. V. \\ Brandi; E. A. Ferreira; A. C. G. Fernandes*; N. R. Valadares \\ Instituto de Ciências Agrárias, Universidade Federal de Minas Gerais, Avenida Universitária, 1000, Universitário, \\ 39404-547, Montes Claros-MG, Brazil \\ *anaclaragoncalvesfernandes@gmail.com \\ (Received on March 29, 2021; accepted on October 14, 2021)
}

\begin{abstract}
The objective of this work was to evaluate the antioxidant and antimicrobial capacity of Kale leaves, as well as to quantify the levels of phenolic compounds and flavonoids present in its aqueous extract, and the viability when added to a fermented milk drink. The leaves were subjected to four treatments: fresh crushed in a blender, fresh sprayed with liquid nitrogen, dried in an oven at $45^{\circ} \mathrm{C}$ for 72 hours and frozen. Antioxidant activity, concentration of total phenolic compounds, flavonoids and antimicrobial activity were determined. To prepare the dairy drink, the amounts of 5\%,10\% and $15 \%$ of the dry extract of Kale leaves were added, as well as $15 \%$ of the dry extract with sorbate and the control treatment. Furthermore, it determined the antioxidant activity and the number of lactic acid bacteria in the drink. The dried and frozen leaves showed better antioxidant activity and, when compared to fresh powdered leaves, they did not differ in phenolic compounds, presenting the best contents. Fresh powdered leaves showed the highest flavonoid yield. The aqueous extracts of kale leaves did not show antibacterial activity against the studied microorganisms. The abstract did not show antioxidant capacity contents of total phenolic compounds and flavonoids in kale subjected to different treatments.
\end{abstract}

Keywords: aqueous extract, Brassica oleracea var. acephala, flavonoids.

O objetivo deste trabalho foi avaliar a capacidade antioxidante e antimicrobiana de folhas de couve, bem como quantificar os teores de compostos fenólicos e flavonóides presentes em seu extrato aquoso e a viabilidade quando adicionado em bebida láctea fermentada. As folhas foram submetidas a quatro tratamentos: frescas trituradas no liquidificador, frescas pulverizadas com nitrogênio líquido, secas em estufa a $45^{\circ} \mathrm{C}$ por 72 horas e congeladas. Determinou-se a atividade antioxidante, concentração de compostos fenólicos totais, flavonóides e atividade antimicrobiana. Para preparo da bebida láctea foram adicionadas as quantidades de $5 \%, 10 \%$ e $15 \%$ do extrato seco de folhas de couve, bem como $15 \%$ do extrato seco com sorbato e o tratamento controle. Além disso, determinou a atividade antioxidante e o número de bactérias lácticas na bebida. As folhas secas e congeladas apresentaram melhor atividade antioxidante e, quando comparadas às folhas frescas em pó, não diferiram em compostos fenólicos, apresentando os melhores teores. Folhas frescas em pó apresentaram maior rendimento de flavonóides. Os extratos aquosos de folhas de couve não apresentaram atividade antibacteriana contra os microrganismos estudados. O resumo não apresentou capacidade antioxidante, teores de compostos fenólicos totais e flavonóides da couve submetida aos diferentes tratamentos.

Palavras-chave: extrato aquoso, Brassica oleracea var. acephala, flavonoides.

\section{INTRODUCTION}

Kale (Brassica oleracea L. var. Acephala) is widely consumed throughout the world [1], being one of the most cultivated and commercialized leafy vegetables in Brazil [2], producing around 161,986 tons per year [3]. This vegetable produces about 3 to 5 kilos of leaves per plant and has a cycle of 6 to 8 months [4], and its leaves can be consumed fresh or minimally processed.

As a Brassicaceae it has a low caloric value $(24-34 \mathrm{kcal} / 100 \mathrm{~g})$ depending on the low protein content (1.44-2.82 g/ $100 \mathrm{~g})$ and an average fiber content of $2.5 / 100 \mathrm{~g}$ [5]. Kale has a higher 
concentration of flavonoids and is a good source of vitamin C (107 mg / $100 \mathrm{~g} \mathrm{FM})$ and carotenoids (2.7 mg / $100 \mathrm{~g} \mathrm{FM)} \mathrm{[6].} \mathrm{Furthermore,} \mathrm{it} \mathrm{is} \mathrm{a} \mathrm{rich} \mathrm{source} \mathrm{of} \mathrm{antioxidants,} \mathrm{phenolic}$ compounds, vitamins, glucosinolates and isothiocyanates among others, and has been referred as a "superfood" [7]. Composite production varies according to the geographical and environmental conditions where the kale is grown, as well as the variety analyzed [8]. Thus, plants of the same variety may have a different composition in bioactive compounds if exposed to different edaphoclimatic conditions during their growth [9]. In studies carried out comparing the conventional planting system and the organic system, contents of phenolic compounds between 173 and $244 \mathrm{mg}$ EAG / 100g in kale leaves and between 86 and $180 \mathrm{mg}$ EAG / 100g in the stems were obtained. Where leaves processed in dry heat and grown in physical systems have higher phenolic contents [10] vegetable extracts have the potential to be used in food products in order to improve the quality and nutritional value of foods [11], thus, kale has phytochemical contents that meet these objectives.

Fermented dairy beverage is a milk product resulting from the mixture of milk and whey, fermented by the action of specific microorganisms, in which it is possible to add other food substances. It is a product of easy acceptance and access to the different age groups, therefore, the supplementation of dairy beverage with kale extract is a promising aspect, thus developing a new product with bioactive compounds of kale, because it is the consumer's desire to acquire enriched and functional products. For besides the kale being highly nutritious, with functional properties, it is easily accessible to populations.

Although kale is a good source of antioxidant, it can present variations of this characteristic at different stages of development, maturation [12], cropping systems [10] and after processing [10, 13]. Additionally, as the type of solvent used in the extraction has considerable influence on the phytochemical content and antioxidant and antimicrobial activity, when the objective is the addition of extracts in foods, solvents that are not toxic for human consumption should be considered.

Therefore, the objective of this study was to evaluate the antioxidant and antimicrobial potential, as well as to quantify the phenolic and flavonoid compounds contents in aqueous kale extract and the viability of the addition fermented dairy beverage.

\section{MATERIAL AND METHODS}

\subsection{Specimen Collection and Preparation}

The leaves of kale (Brassica oleracea var. Achephala) "cultivar Manteiga" were harvested in the experimental garden of the UFMG Institute of Agrarian Sciences in Montes Claros, at an altitude of $630 \mathrm{~m}$, latitude $16^{\circ} 45^{\prime} \mathrm{S}$ and longitude $43^{\circ} 51^{\prime} \mathrm{W}$ from February to July 2017 and taken to the UFMG Aromatic Medicinal Plants Laboratory. The samples were screened in order to select tradable leaves and chlorinated solution cleaning.

The kale leaves were submitted to four treatments. In the first, after sanitization, about $50 \mathrm{~g}$ of leaves were manually chopped, then shredded in a blender and were immediately analyzed. This treatment was called shredded fresh leaf (SFL). In the second treatment the fresh leaves $(50 \mathrm{~g})$ were manually chopped and sprayed in liquid nitrogen in mortar, and immediately analyzed, it was named fresh sprayed leaf (FLP).

For the third treatment, called dry leaf (DL), the whole leaves $(200 \mathrm{~g})$ were dried in an air circulation oven at $45^{\circ} \mathrm{C}$ for 72 hours, then crushed and stored under freezing $\left(-20^{\circ} \mathrm{C}\right)$ for 60 days to analyze the antioxidant activity of phenolic and flavonoid compounds. In the fourth treatment, about $50 \mathrm{~g}$ of the sanitized leaves were manually chopped, then sprayed with liquid nitrogen and stored in Falcon tubes under freezing $\left(-20^{\circ} \mathrm{C}\right)$ temperature for up to 60 days for analysis of antioxidant activity, phenolic compounds and flavonoids, this treatment was called frozen leaf (FL). 


\subsubsection{Preparation of aqueous kale extracts}

To prepare the aqueous extracts, $2 \mathrm{~g}$ of the leaves were placed in a conical flask and $20 \mathrm{~mL}$ of distilled water was added. The choice of water as a solvent is mainly due to non-toxicity, ease handling and its use in food. The container was covered with aluminum foil and for each treatment four repetitions were prepared. The system was kept in orbital agitation (GO shaker, SK-180-Pro) at $320 \mathrm{rpm}$ for one hour and then left in an ultrasonic bath (Sanders, SoniClean 6) for 25 minutes. The extract was filtered on filter paper and the supernatant collected in an amber flask, then stored under refrigeration $\left(4^{\circ} \mathrm{C}\right)$ until the time of analysis.

\subsection{Antioxidant Activity Analysis}

Antioxidant activity analysis was performed using the free radical DPPH (2,2-diphenyl-1picrylhydrazyl) according to the methodology of Brand-Williams et al. (1995) [14] with adaptations. For the reaction, aqueous kale extract $(0.2 \mathrm{~mL})$ was added to glass tubes containing $0.05 \mathrm{mM}$ DPPH solution $(3.0 \mathrm{~mL})$ diluted in ethanol. The tubes were vortexed for 30 seconds then left in a dark environment for 30 minutes. Absorbance reading was performed on a spectrophotometer (Micronal, B582) at $517 \mathrm{~nm}$. The mixture of ethanol $(3.0 \mathrm{~mL})$ and distilled water $(0.2 \mathrm{~mL})$ was used as blank.

The percentage of free radical sequestration (FRS) was calculated using the following equation: FRS $(\%)=(($ Acontrol-Sample $) /$ Acontrol $) \times 100$, where Acontrol refers to the absorbance of the control reaction $(3.0 \mathrm{~mL}$ of solution DPPH and $0.2 \mathrm{~mL}$ of distilled water) and Samples the reaction absorbance between the samples of kale and DPPH extracts.

Efficient concentration (EC50) values were determined. This is the minimum concentration required for kale extract to reduce by $50 \%$ the initial DPPH radical of the reaction. For the construction of the curve, five concentrations of each treatment were selected, being for dry leaves from 1.56 to $25 \mathrm{mg} \mathrm{mL}^{-1}$ and for the other three treatments from 6.25 to $100 \mathrm{mg} \mathrm{mL}^{-1}$.

\subsection{Determination of total phenolic compounds}

For the determination of phenolic compounds, the methodology described by Singleton et al. (1999) [15] was followed. For each treatment, four quadruplicate repetitions were performed. For expression of the results, a gallic acid calibration curve (Sigma-Aldrich) was constructed at concentrations of $0.005,0.01,0.02,0.04 \mathrm{mg} \mathrm{mL}^{-1}\left(\mathrm{R}^{2}=0.99\right)$. Thus, the results were expressed as $\mathrm{mg} \mathrm{EAG} \mathrm{g}^{-1}$ dry weight. EAG was the gallic acid equivalent. Samples were diluted as necessary to meet standard curve limits.

\subsection{Determination of total flavonoids}

Flavonoids were determined according to the methodology described by Dewanto et al. (2002) [16]. For each treatment, four quadruplicate repetitions were performed. To express the results catechin calibration curves (Green select Phytosome, $88.88 \%$ purity) were constructed using concentrations of 100, 200, 300, 400, and $500 \mu \mathrm{g} \mathrm{mL}^{-1}$ and quercetin (Sigma-Aldrich) at 50, 100, 200, 300, and $400 \mu \mathrm{g} \mathrm{mL}^{-1}(\mathrm{R} 2=0.99)$. The results were expressed as mg EC50 $\mathrm{g}^{-1}$ dry weight and $\mathrm{mg} \mathrm{EQ} \mathrm{g}{ }^{-1}$ dry weight. EC50 was the efficient concentration to neutralize $50 \%$ of free radicals.

\subsection{Screening of antimicrobial activity}

The plate diffusion method was used on paper discs, which was based on the methodology proposed by CLSI (2019) [17] with changes. The pathogenic bacteria Staphylococcus aureus ATCC 43300, Escherichia coli ATCC 8759 and Salmonella choleraesuis ATCC 10708 were suspended in sterile saline and the turbidity was compared to the McFarland 0.5 standard. The amount of $15 \mu \mathrm{L}$ of this suspension was inoculated in Petri dishes containing culture medium of 
Mueller Hinton nutrient agar. Subsequently, $6 \mathrm{~mm}$ diameter filter paper discs impregnated with $30 \mu \mathrm{L}$ of kale extract from the four treatments at a concentration of $100 \mathrm{mg} \mathrm{mL}^{-1}$ were placed. Antibiogram plates were incubated at $37^{\circ} \mathrm{C}$ for a period of 24 hours. After incubation, inhibition halos were measured. Three replicates of each microorganism were made.

\subsection{Production of Kale Extract Fermented Dairy Drink}

The following ingredients were used to produce the fermented dairy drink: Whole UHT milk, whey powder, mineral water, sugar, milk yeast composed of Streptococcus thermophilus and Lactobacillus delbrueckii ssp bulgaricus (Crs. Hansen), modified starch thickener and kale extract. The drink was produced with the ratio of $75 \%$ milk and $25 \%$ whey, this proportion was

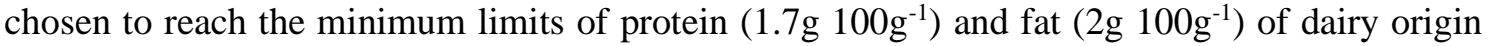
[18].

For preparation of the kale extract, the treatment that presented the best results in the analysis of antioxidant activity with more than $50 \%$ of radical sequestration, determination of total phenolics and flavonoids regarding the extract was chosen. The extract was prepared at a concentration of $100 \mathrm{mg} \mathrm{mL}^{-1}$ and in addition to the steps already mentioned in the preparation, the extract was microfiltered $(0.22 \mu \mathrm{m})$ for sterilization purposes and added to the milk in the proportions of 5,10 and $15 \%(\mathrm{v} / \mathrm{v})$. For the positive control potassium sorbate preservative concentration of $0.03(3.0 \% \mathrm{~m} / \mathrm{v})$ was used according to the limit established by the technical regulation of identity and quality of dairy drink [18].

For the production process of fermented dairy drink, the methodology described by EPAMIG (2010) [19] was followed. Microbiological and antioxidant analyzes were performed on milks after manufacture.

\subsection{Analysis of antioxidant activity of fermented dairy drink}

The antioxidant activity analyses of the fermented dairy drink were performed using the free radical DPPH (2,2-diphenyl-1-picrylhydrazyl, Sigma-Aldrich) according to the methodology of Brand-Williams et al. (1995) [14] with adaptations by Skrede et al. (2004) [20].

First the drinks were diluted in methanol 1:0.5. Following, in triplicate, $100 \mu \mathrm{l}$ of the diluted samples were placed in a methanol treatment (control) in Falcon tubes and $3.9 \mathrm{~mL}$ of the DPPH radical (0.0277 g DPPH L-1 methanol) was added. The mixture was left in a dark environment for 30 minutes and then centrifuged at $4000 \mathrm{rpm}$ for $10 \mathrm{~min}$. Thereafter, the absorbance of the supernatant was read on a spectrophotometer at $515 \mathrm{~nm}$ using methanol as blank.

\subsection{Lactic bacterial count of fermented milk drink}

In all produced milk lactic bacteria were counted. The first dilution was made with $25 \mathrm{~mL}$ of sample in $225 \mathrm{~mL}$ of $0.1 \%(\mathrm{p} / \mathrm{v})$ peptone saline and homogenization. From the initial dilution $\left(10^{-}\right.$ ${ }^{1}$ ), further dilutions were made using the above diluent solution. Each desired dilution was inoculated into the MRS Agar medium (De Man, Rogosa and Sharpe), the plates were incubated at $37^{\circ} \mathrm{C}$ for 48 hours, after which the lactic acid bacteria were counted [21].

\subsection{Statistical analysis}

The experimental design was completely randomized with four replications and the results were analyzed by the variance analysis method and the means compared by the Tukey test at a 5\% significance level using the $\mathrm{R}$ statistical software and the ExpDes.pt package. 


\section{RESULTS AND DISCUSSION}

\subsection{Antioxidant activity, total phenolic compounds and flavonoids}

Regarding antioxidant activity, freshly harvested leaves subjected to shredding techniques using a blender and sprayed on liquid nitrogen did not differ statistically (Table 1). This shows that, in this case, differences in leaf particle size (FLP> SFL) as well as the rapid inhibition of enzymatic activity by low nitrogen temperature were not sufficient to influence DPPH sequestration capacity.

Table 1-Antioxidant activity, EC 5 , content of total phenolic and flavonoid compounds in aqueous kale extract.

\begin{tabular}{|c|c|c|c|c|c|}
\hline \multirow[b]{2}{*}{ Treat. } & \multirow[b]{2}{*}{$\mathbf{A A}(\%)$} & \multirow{2}{*}{ 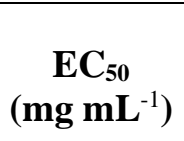 } & \multirow{2}{*}{$\begin{array}{l}\text { Phenolics } \\
\text { (mgEAG g- }{ }^{1} \text { dw) }\end{array}$} & \multicolumn{2}{|c|}{ Flavonoides } \\
\hline & & & & $\operatorname{mgEC~} g^{-1} \mathrm{dw}$ & $\operatorname{mgEQ} \mathrm{g}^{-1} \mathrm{dw}$ \\
\hline DL & $78.75 \pm 4.79 a$ & $\begin{array}{l}10.00 \\
\pm 1.20\end{array}$ & $43.53 \pm 3.87 \mathrm{a}$ & $26.00 \pm 2.70 \mathrm{~b}$ & $14.59 \pm 1.61 \mathrm{~b}$ \\
\hline FL & $71.20 \pm 2.06 \mathrm{a}$ & $\begin{array}{c}43.80 \pm \\
3.50\end{array}$ & $42.94 \pm 9.11 \mathrm{a}$ & $23.76 \pm 2.06 \mathrm{~b}$ & $11.53 \pm 1.24 \mathrm{~b}$ \\
\hline SFL & $\begin{array}{l}63.16 \pm 5.12 \\
b\end{array}$ & $\begin{array}{c}61.77 \pm \\
5.13\end{array}$ & $40.22 \pm 3.76 \mathrm{ab}$ & $49.27 \pm 8.27 \mathrm{a}$ & $26.83 \pm 4.96 \mathrm{a}$ \\
\hline FLP & $\begin{array}{l}62.04 \pm 0.91 \\
b\end{array}$ & $\begin{array}{l}76.15 \\
\pm 6.01 \\
\end{array}$ & $29.89 \pm 2.73 b$ & $19.91 \pm 0.82 b$ & $9.22 \pm 0.49 b$ \\
\hline
\end{tabular}

Treatments: AA: Antioxidant Activity; DL: Dry leaf; FL: Frozen leaf; SFL: Fresh Leaf Sprayed; FLP: Fresh shredded leaf; dw: dry weight. Equal letters in the columns do not differ statistically by Tukey's test at 5\% significance.

The percentages of inhibition of DPPH radical by the fresh leaves of this study are in agreement with those found by Korus (2011) [12] who obtained values in the range of 40.7 to $65.5 \%$ for fresh kale. The results also agree with those found by Rigueira et al. (2016) [10], who found $68.6 \%$ in unprocessed kale leaves. However, the percentages of FRS of fresh leaves are below those found by Melo et al. (2006) [22] in raw kale leaves with a value of $90.49 \%$, although this percentage did not differ from $60.16 \%$ (curly lettuce). It should be noted that the studies by Rigueira et al. (2016) [10] and Melo et al. (2006) [22] used methanol and ethanol as solvents. In the present study, distilled water was used. As the type of solvent used for extraction has a direct influence on the phytochemical composition of the extract, it also influences the antioxidant potential [11,23].

Studies report that vegetables subjected to different processing techniques may change their antioxidant potential $[10,24]$, as well as, the use of different types of solvents influences the content of extracted phytochemicals, and consequently the antioxidant activity and antimicrobial activity. For the purpose of adding extracts into foods, the ideal is the choice of non-toxic solvents that is easy to handle, and water meets these requirements, however, its effectiveness in extraction must be known.

The FLP and SFL of this study, according to the classification of Melo et al. (2006) [22], showed moderate DPPH sequestration capacity with values from 60 to $70 \%$. It is important to remember that the condition of fresh shredded leaves resembles the juice of kale, shredded in a blender with water.

DL presented the highest numerical value of antioxidant activity, but did not differ from FL (Table 1). Other studies also found an increase in AA as a function of heat application, such as data from Rigueira et al. (2016) [10] by applying dry heat (frying for $3 \mathrm{~min}$ ) on kale leaves as well as Murador et al. (2016) [13] and Girgin and El (2015) [1] observed an increase of 186.9\% 
in cauliflower and 39\% in cauliflower, respectively, in antioxidant activity with steam cooking compared to raw vegetables.

This increase in antioxidant activity as a function of heat in fresh leaves may be due to several factors, such as degradation of compounds, leading to variation in total phenolic content and composition [13] and breakdown of cell components, favoring release of antioxidant compounds [1]. Simply by drying favors the concentration of antioxidant compounds due to the lower amount of water compared to fresh vegetables.

DL results are close to those found by Rigueira et al. (2016) [10] when analyzing kale leaves submitted to dry heat and presented DPPH inhibition capacity from $72.5 \%$ to $86.9 \%$.

FL, as well as DL, showed the best results in DPPH radical sequestration (71.20\%). Studies show antioxidant stability during freezing, such as blackberry fruits with up to 60 days of storage, ranging from 80.55 to $77.94 \%$ of DPPH inhibition [25].

From the absorbance values of the different concentrations of the extracts in reaction with DPPH the EC50 calculations were made for the treatments (Table 1). These values which are close to those found by Armesto et al. (2016) [26] in boiled kale leaves $\left(22.50 \mathrm{mg} \mathrm{mL}^{-1}\right)$, presented lower yield than those found by Jaiswal et al. (2012) [11] for broccoli and cabbage, which ranged from 0.71 to $1.41 \mathrm{mg} \mathrm{mL}^{-1}$ depending on the solvent and smaller than cauliflower leaves with a value of $2.27 \mathrm{mg} \mathrm{mL}^{-1}$ [27]. Knowing the antioxidant capacity of foods can help with research that assesses dietary intake and planning for increased antioxidant intake.

It was observed that in the DL extracts at concentrations of 25 and $100 \mathrm{mg} \mathrm{mL}^{-1}$, after the reaction with the DPPH radical, there was precipitate formation, and the higher the concentration the greater the precipitate formation. No reports of this have been observed in the literature, so it is believed that precipitate formation is related to higher leaf solids concentration.

The nutritional interest for kale is mostly related to its total phenolic compounds, as it is generally rich in polyphenols, and among its properties for human health, one of the most important is the antioxidant activity [19]. DL, FL and SFL did not differ statistically for total phenolic compounds (Table 1). FSL, however, had lower total phenolic content, but did not differ from SFL ( $p>0.05$ ). Before transforming the values to the unit of $\mathrm{mg} \mathrm{EAG} \mathrm{g}^{-1}$ dry weight, we obtained the data of mg EAG mL of extract ${ }^{-1}$. It was observed that the extract with DL had about 10 times higher total phenolic content $\left(4,06 \pm 0.36 \mathrm{mg} \mathrm{EAG} \mathrm{mL} \mathrm{extract}{ }^{-1}\right)$ than the other treatments.

Naguib et al. (2012) [28] found values from 7.68 to 13.82 mg EAG g-1 dry weight when evaluating the effect of organic fertilizers on two broccoli cultivars. Results are also above those found for Galega kale (13.18 mg EAG g-1 dry weight) [29] and are in agreement with Armesto et al. (2016) [26] in kale cultivate "Galega".

The heat treatment and consequently the dehydration showed no significant changes in the total phenolic content in relation to the fresh leaves (pulverized). This behavior was similar to that observed by Fiol et al. (2013) [30] who submitted three kale cultivars at $100^{\circ} \mathrm{C}$ for two and four hours, and the total phenolic content did not differ between the cooked samples and the raw kale. The authors point out that the simultaneous degradation of some compounds results in an increase of other neoformed compounds or substances which compensates for the loss of total phenolic components and, therefore, there was no change in the total phenolic content [30].

The higher content of total phenolic compounds in FL compared to FSL is in agreement with Alanís-Garza et al. (2015) [31] who evaluated the effect of industrial freezing $\left(-20^{\circ} \mathrm{C}\right)$, therefore the same temperature of the present work, on the stability of bioactive molecules in seven commercial broccoli cultivars. As a result, total phenols remained constant in most cultivars and in some were slightly increased. This suggests that bioactive compounds in frozen broccoli would be more bioavailable than in raw vegetables [31], which corroborates our findings.

Therefore, plant freezing can lead to the development of ice crystals within the plant matrix, and these crystals can affect the structure of cell membranes, inducing changes in their permeability, improving the compound extraction process [31]. In addition, studies report that freezing leads to higher polyphenol retention as part of plant response to low temperature stress [24].

In the present study, the leaves before being frozen were sprayed with liquid nitrogen, so there may have been inhibition of kale enzymes, which may influence phenolic metabolism, in addition 
to cell membrane rupture, which could increase the extractability of the compounds. SFL also underwent these processes of liquid nitrogen and membrane rupture through spraying, which may justify their close contents, resulting in greater accessibility of the compounds to the extraction solvent, as the total phenolic compounds are water soluble.

There was no significant $(\mathrm{p}>0.05)$ correlation between antioxidant activity and total phenolic content $(\mathrm{R}=0.7372)$. SFL showed lower antioxidant power than DL and FL, but did not differ from these treatments in relation to the phenolic compounds, because phenolic compounds are not the only components that influence antioxidant activity. Studies show that the antioxidant capacity of Brassica oleracea species is related to the content and composition of phenolics, flavonoids, anthocyanins, lutein, vitamin $\mathrm{C}$ and neochlorogenic acids [24].

Among the total phenolic compounds, flavonoids and phenolic acids are the most characterized groups in Brassica. Flavonoids protect plants against UV radiation, pathogenic microorganisms, insects and plant-eating animals, and also react as antioxidants in defense against reactive oxygen species (ROS) [32]. The treatments DL, FL and FSL did not differ statistically in flavonoid content (Table 1), therefore, the application of heat as well as the low temperature to kale leaves provides extracts with high total phenolic contents, but low amounts of flavonoids. Crushing using a blender can be considered an inefficient technique for extracting both compounds. SFL in liquid nitrogen, which is characterized by their smaller particle size and rapid enzymatic inhibition, provided extracts with higher flavonoid content (26.83 mg EQ g dry weight ${ }^{-1}$ and $49.27 \mathrm{mg} \mathrm{EC50}^{-1}$ g dry weight ${ }^{-1}$ ).

Similar situation was found by Bhandari and Kwak (2015) [27] when analyzing cauliflower and broccoli, found that the total phenol content was higher in the inflorescences, while the total flavonoid content was higher in the leaf tissue, and there was no correlation between total phenolics and flavonoids. In the present study there was no significant correlation ( $p>0.05)$ between flavonoids and antioxidant activity $(\mathrm{R}=-0.21883)$, as well as flavonoids and phenolic compounds $(\mathrm{R}=0.3438)$. The $\mathrm{DL}, \mathrm{FL}$ and SFL presented higher content of total phenolic compounds. The highest content of flavonoids was presented in SFL.

The results found for flavonoid contents are in agreement with those found by Bhandari and Kwak (2015) [27] in broccoli and cauliflower and also corroborate the findings by Naguib et al. (2012) [29] for broccoli. Before transforming the values to the unit of $\mathrm{mg} / \mathrm{g}$ dry weight, the extract $\mathrm{mg} \mathrm{mL}^{-1}$ data were obtained, it was noticed that the extract pf dried leaves had the flavonoid content (1.37 mg EQ mL extract $\left.{ }^{-1}\right)$ and $\left(2.43 \mathrm{mg}\right.$ EC50 mL extract $\left.{ }^{-1}\right)$ about 10 times higher than FL and FSL treatments and about five times higher than FCL treatments.

DL and FL, stored for up to 60 days for flavonoid analysis, there may have been competition in the production of other phenolic compounds, a large group to which flavonoids belong. In a study with kale Park et al. (2014) [32] stated that based on biosynthetic pathways, phenolic acids had a competitive relationship with anthocyanidins and flavonols.

In this study the kale leaves were analyzed for shredding and preservation techniques. The use of water as a solvent and the concentration of $0.1 \mathrm{~g} \mathrm{~mL}^{-1}\left(\right.$ or $\left.100 \mathrm{mg} \mathrm{mL}^{-1}\right)$ in kale leaves presented good results of antioxidant activity, total phenolic compounds and flavonoids. This fact has high relevance, especially regarding the possible addition of these extracts in foods as enrichment of antioxidant potential.

\subsection{Antimicrobial activity of kale extracts}

There was no inhibition halo formation of any of the aqueous kale extracts for S. aureus, E. coli and Salmonella bacteria. Differing results were found in studies that evaluated the antimicrobial action on Brassica oleracea plants using aqueous extract, such as Begum and Poonkothai (2013) [23] and Vale et al. (2015) [33]. In both studies there was a high concentration of the extract, either by lyophilization or by heating. In addition to the experimental conditions, non-inhibition may have been due to factors related to the analyzed leaves, such as the selected cultivar, soil, region climate and cultivation. The cultivation system (conventional and organic) and processing (dry and wet heat) directly affect the chemical composition of the plant [10] and the extraction solvents also influence the recovery of secondary metabolites [23]. Other studies 
should be performed by diversifying the concentration of the extracts and the way of extraction of these compounds.

Other studies have also found that water is less effective in extracting antimicrobial compounds [34].

The kale leaves studied in this research and submitted to these extraction techniques did not show antimicrobial action. Therefore, further work should be done by studying other cultivars and extraction methodologies.

\subsection{Fermented milk drink added with aqueous kale extract}

The aqueous extracts of kale leaves submitted to the drying technique showed better results of antioxidant activity, EC50, total phenolic compounds and flavonoids (depending on the extract) so this treatment was chosen for addition to the fermented milk drink. The dairy drink with $15 \%$ extract and the drink with $15 \%$ extract with sorbate did not differ statistically and showed higher antioxidant activity (Table 2). Therefore, the antioxidant activity of the control drink (11.65\%) is due to the milk and whey ingredients. Ribeiro et al. (2014) [35] found almost 5\% antioxidant activity in fermented milk. In this work, the addition of potassium sorbate additive had no antioxidant effect on the milk. Thus, the fermented milk drink already has the antioxidant potential and the addition of $15 \%$ of the aqueous extract of dried kale leaf increased this potential more than three times.

Table 2 - Antioxidant activity and lactic acid count of fermented dairy drinks with addition of aqueous kale extract and control.

\begin{tabular}{|c|c|c|}
\hline Treat. & $\mathrm{AA}(\%)$ & BAL $\left(\right.$ UFC mL m $\left.^{-1}\right)$ \\
\hline $5 \%$ drink & $26.83 \pm 2.57 b$ & $2.13 \times 10^{7}$ \\
\hline $10 \%$ drink & $28.34 \pm 2.70 b$ & $>10^{7}$ \\
\hline $15 \%$ drink & $36.82 \pm 3.37 \mathrm{a}$ & $>10^{7}$ \\
\hline 15\% Sorbate Drink & $36.32 \pm 5.27 \mathrm{a}$ & $3.7 \times 10^{6}$ \\
\hline Sorbate Drink (Control) & $11.65 \pm 1.90 \mathrm{c}$ & $1.49 \times 10^{7}$ \\
\hline
\end{tabular}

Treatments - AA: Antioxidant Activity; BAL: lactic acid bacteria. Equal letters do not differ by Tukey test at $5 \%$ significance level.

There was no difference in antioxidant activity between milks added with 5\% and $10 \%$ of kale extract, but they were still 2.3 and 2.4 times higher than the control, respectively. Regarding the lactic bacteria count, the drinks added in the extract in 5\%,10\%,15\% and 15\% with sorbate, had lactic bacteria counts above $106 \mathrm{CFU} \mathrm{mL}^{-1}$ (Table 2), so they are in accordance with current legislation [18]. Therefore, the presence of the extract in the drink did not inhibit the growth of these bacteria, as they did not differ from the control.

Aqueous kale extract is a promising ingredient for both food and consumer due to the fact that it will inhibit the oxidation of the kale and it is a food enriched with bioactive kale compounds and increased antioxidant activity. The fermented milk drink added with $15 \%$ aqueous kale extract showed better antioxidant performance.

\section{CONCLUSIONS}

The application of heat as well as the low temperature to the kale leaves provide extracts with high antioxidant activity, high total phenolic contents, but low amounts of flavonoids. Fresh leaves sprayed with liquid nitrogen provide extracts with higher flavonoid content. There is no antimicrobial action of aqueous kale extracts against $S$. aureus, E. coli and Salmonella bacteria. Other studies should be performed by diversifying the concentration of the extracts and the way of extracting these compounds. 
The use of water as a solvent and the concentration of $0.1 \mathrm{~g} \mathrm{~mL}^{-1}$ in kale leaves obtained good results of antioxidant activity, total phenolic compounds and flavonoids. Aqueous kale extract is promising for addition to fermented milk drink as it can inhibit the oxidation of the milk without interfering with the fermentation process.

Due to the demand for functional foods, these extracts can also be added in other foods low in antioxidant activity. Further studies should be done for sensory acceptance of fermented milk drink supplemented with kale extract.

\section{ACKNOWLEDGEMENTS}

The present work was carried out with the support of the Coordination for the Improvement of Higher Education Personnel (CAPES) - Finance Code 001, the National Council for Scientific Development (CNPQ) and the Minas Gerais Research Support Foundation (FAPEMIG).

\section{BIBLIOGRAPHIC REFERENCES}

1. Girgin N, El SN. Effects of cooking on in vitro sinigrin bioaccessibility, total phenols, antioxidant and antimutagenic activity of cauliflower (Brassica oleraceae L. var. Botrytis). J Food Compos. 2015 Feb;37:119-27. doi: 10.1016/j.jfca.2014.04.013

2. Ponce FS, Trento DA, Toledo CAL, Antunes DT, Zanuzo MR, Dallacort R, et al. Low tunnels with shading meshes: An alternative for the management of insect pests in kale cultivation. Scientia Horticulturae. 2021 Oct;288:110284. doi: 10.1016/j.scienta.2021.110284

3. Instituto Brasileiro de Geografia e Estatística (IBGE). Cultivo da Couve [Internet]; 2017 [access in 2021 Sep] Available from: https://www.ibge.gov.br/explica/producao-agropecuaria/couve/br

4. Trani PE, Tivelli SW, Blat SF, Prela-Pantano A, Teixeira EP, Araújo HS, et al. Couve de folha: do plantio à pós-colheita. Campinas (SP): Instituto Agronômico; 2015. (Boletim Técnico IAC, 214).

5. Heimler D, Vignolini P, Dini MG, Vincieri FF. Romani, A. Antiradical activity and polyphenol composition of local Brassicaceae edible varieties. Food Chem. 2006;99(3):464-9.

6. Mandic AM, Dials SM, Ćetković GS, Čanadanović-Brunet JM. Tumbas VT. Polyphenolic composition and antioxidant activities of grape seed extract. Int J Food Properties. 2008;11(4):713-26. doi: $10.1080 / 10942910701584260$

7. Šamec D, Urlić B, Salopek-Sondi B. Kale (Brassica oleracea var. acephala) as a superfood: review of the scientific evidence behind the statement. Crit Rev Food Sci Nutr. 2019;59(15):2411-22. doi: $10.1080 / 10408398.2018 .1454400$

8. Ferioli F, Giambanelli E, D'Antuono LF, Costa HS, Albuquerque TG, Silva AS, et al. Comparison of leafy kale populations from Italy, Portugal, and Turkey for their bioactive compound content: phenolics, glucosinolates, carotenoids, and chlorophylls. J Sci Food Agric. 2013;93(14):3478-89. doi: $10.1002 /$ jsfa. 6253

9. Liu RH. Dietary bioactive compounds and their health implications. J Food Sci. 2013;78(suppl 1):A1825. doi: 10.1111/1750-3841.12101

10. Rigueira GDJ, Bandeira AVM, Chagas CGO, Milagres RCRM. Atividade antioxidante e teor de fenólicos em couve-manteiga (Brassica oleracea l. var. acephala) submetida a diferentes sistemas de cultivo e métodos de preparo. Semina: Ciênc Biol Saúde. 2016 Nov;37(2):3-12. doi: 10.5433/16790367.2016v37n2p3

11. Jaiswal AK, Abu-Ghannam N, Gupta S. A comparative study on the polyphenolic content, antibacterial activity and antioxidant capacity of different solvent extracts of Brassica oleracea vegetables. Int J Food Sci Tech. 2012 Nov;47(2):223-31. doi: 10.1111/j.1365-2621.2011.02829.x

12. Korus A. Level of vitamin C, polyphenols, and antioxidant and enzymatic activity in three varieties of kale (Brassica oleracea L. var. acephala) at different stages of maturity. Int J Food Pro. 2011 Aug;14(5):1069-80. doi: 10.1080/10942910903580926

13. Murador DC, Mercadante AZ, Rosso VVD. Cooking techniques improve the levels of bioactive compounds and antioxidant activity in kale and red Kale. Food Chem. 2016 Apr;196:1101-7. doi:10.1016/j.foodchem.2015.10.037

14. Brand-Williams W, Cuvelier ME, Berset C. Use of a free radical method to evaluate antioxidant activity. LWT - Food Sci Tech. 1995 Jun;28(1):25-30. doi: 10.1016/S0023-6438(95)80008-5

15. Singleton VL, Orthofer R, Lamuela-Raventós RM. Analysis of total phenols and other oxidation substrates and antioxidants by means of Folin-Ciocalteu reagent. Method Enzymol. 1999 Jan;299:15278. doi: 10.1016/S0076-6879(99)99017-1 
16. Dewanto V, Wu X, Adom KK, Liu RH. Thermal processing enhances the nutritional value of tomatoes by increasing total antioxidant activity. J Agr Food Chem. 2002 Apr;50(10):3010-14. doi: $10.1021 /$ jf0115589

17. Clinical and Laboratory Standards Institute (CLSI). Performance standards for antimicrobial susceptibility testing. 29th ed. CLSI suplement M100. Wayne (PA): Clinical and Laboratory Standards Institute; 2019.

18. Brasil. Ministério da Agricultura, Pecuária e Abastecimento. Instrução Normativa ${ }^{\circ} 16$, de 23 de agosto de 2005. Anexo: Regulamento técnico de identidade e qualidade de bebida láctea. Diário Oficial da União. 24 ago 2005;163(Seção 1):7-.10 Available from: https://wp.ufpel.edu.br/inspleite/files/2016/03/Instru\%C3\%A7\%C3\%A3o-normativa-n\%C2\%B0-16de-23-de-agosto-de-2005.pdf

19. Empresa de Pesquisa Agropecuária de Minas Gerais (EPAMIG). Tecnologia de fabricação de bebida láctea fermentada e não fermentada [Internet]. [Minas Gerais]: EPAMIG; 2010 [access in 2019 Mar 26]. Available from: http://www.epamig.br/download/cartilha-tecnologia-de-fabricacao-de-bebidalactea-fermentada-e-nao-fermentada/

20. Skrede G, Larsen VB, Aaby K, Jørgensen AS, Birkeland SE. Antioxidative properties of commercial fruit preparations and stability of bilberry and black currant extracts in milk products. J Food Sci. 2004 May;69(9):351-6. doi: 10.1111/j.1365-2621.2004.tb09948.x

21. International Standard Organization. ISO 7889: Yogurt - Enumeration of characteristics microorganisms - Colony count technique at $37^{\circ} \mathrm{C}$. Geneva (CH): ISO; 2003.

22. Melo EA, Maciel MIS, Lima VLAG, Leal FLL, Caetano ACS, Nascimento RJ. Capacidade antioxidante de hortaliças usualmente consumidas. Ciênc Tecnol Aliment. 2006 Jul;26(2):639-44.

23. Begum AR, Poonkothai M. In vitro antimicrobial activity and phytochemical analysis of Brassica oleracea. Int J Pharm Pharm Sci. 2013;5(2):405-8.

24. Sikora E, Cieślik E, Leszczyńska T, Filipiak-Florkiewicz A, Pisulewski PM. The antioxidant activity of selected cruciferous vegetables subjected to aquathermal processing. Food Chem. 2008 Mar;107(1):55-9. doi: 10.1016/j.foodchem.2007.07.023

25. Haida KS, Silva FJ, Coelho SRM, Lima DS, Abrão RM, Haida K. Caracterização físico-química e atividade antioxidante de amoreira-preta (Morus nigra L.). Rev Bras Ciênc Saúde. 2014 April;12:2128. doi:10.13037/rbcs.vol12n40.2185

26. Armesto J, Gómez-Limia L, Carballo J, Martínez S. Effects of different cooking methods on some chemical and sensory properties of Galega kale. Int J Food Sci Tech. 2016 Jul;51(9):2071-80. doi: 10.1111/ijfs.13181

27. Bhandari SR, Kwak J-H. Chemical composition and antioxidant activity in different tissues of brassica vegetables. Molecules. 2015 Jan;20(1):1228-43. doi: 10.3390/molecules20011228

28. Naguib AEMM, El-Baz FK, Salama ZA, Hanaa HAEB, Ali HF, Gaafar AA. Enhancement of phenolics, flavonoides and glucosinolates of Broccoli (Brassica olaracea, var. Italica) as antioxidants in response to organic and bio-organic fertilizers. J Saudi Soc Agr Sci. 2012 Jun;11(2):135-42. doi: 10.1016/j.jssas.2012.03.001

29. Oliveira SM, Ramos IN, Brandão TRS, Silva CLM. Effect of air-drying temperature on the quality and bioactive characteristics of dried Galega kale (Brassica oleracea L. var. acephala). J Food Process Pres. 2015 Apr;39(6):2485-96. doi: 10.1111/jfpp.12498

30. Fiol M, Weckmüller A, Neugart S, Schreiner M, Rohn S, Krumbein A, et al. Thermal-induced changes of kale's antioxidant activity analyzed by HPLC-UV/Vis-online-TEAC detection. Food Chem. 2013 Jun;138(2-3):857-65. doi: 10.1016/j.foodchem.2012.10.101

31. Alanís-Garza, P.A., Becerra-Moreno, A., Mora-Nieves, J.L., Mora-Mora, J.P., and Jacobo-Velázquez, D.A. Effect of industrial freezing on the stability of chemopreventive compounds in broccoli. Int J Food Sci Nutr. 2015 Feb;66:282-288. doi: 10.3109/09637486.2015.1007451

32. Park S, Arasub MV, Jiangc N, Choic S-H, Limd YP, Parkc J-T, et al. Metabolite profiling of phenolics, anthocyanins and flavonols in Kale (Brassica oleracea var. capitata). Ind Crop Prod. 2014 Sep;60:814. doi: 10.1016/j.indcrop.2014.05.037

33. Vale AP, Santos J, Melia N, Peixoto V, Brito NV, Oliveira MBPP. Phytochemical composition and antimicrobial properties of four varieties of Brassica oleracea sprouts. Food control. 2015 Sep;55:24856. doi: 10.1016/j.foodcont.2015.01.051

34. Alvarenga AL, Schwan RF, Dias DR, Schwan-Estrada KRF, Bravo-Martins CEC. Atividade antimicrobiana de extratos vegetais sobre bactérias patogênicas humanas. Rev Bras Plantas Med. 2007 Mar;9(4):86-91.

35. Ribeiro OAS, Boari CA, Fonseca CM, Figueiredo SP, Neumann D, Abreu LR. Bebida láctea fermentada formulada com Camellia sinensis. B CEPPA. 2014 Jul;32(2):289-304. 